\title{
Improvement High Order Think Skill with Think Pair and Share Learning in Social Arithmetic of the Sekolah Menengah Pertama (SMP) School of Medan
}

\author{
Pargaulan Siagian \\ Mathematics Education Program, Post Graduate Program \\ State University of Medan, Indonesia
}

\begin{abstract}
The objective of this study is to yield a certain device of learning with think pair and share of outcomes : book of teacher, book of student, learning program plan (LPP), activity sheet of student, authentic assessment in social arithmetic with ability high order thinking in valid, practical, and effective. Procedure to develop them is according to a 4-D model scheme covering the processes of define, design, develop, and disseminate, in a TPS learning model, and RPP in social arithmetic learning. In execution, the process such as prepare component of mathematics learning material of SMP level, to produce books of teacher, book of student, RPP, activity sheet of student (LKS) and assessment to be applied on SMP level refers to material of learning in social arithmetic and existed in ability of high order thinking skill for 2018. To do disseminate is to apply learning material of mathematic to SMP in order to produce: books of teacher, book of student, RPP, LKS, and assessment of high order thinking skill and disseminate them to teachers of SMP and train them accordingly.
\end{abstract}

Keywords : define, design, develop, and disseminate.

\section{BACKGROUND}

The improvement of learning tool with think pair and share learning model be valid, practical and effective in order to upgrade high order thinking skill on schools is to effort and push their ability up in resources dealing with global competition. Up grading quality of learning it means to improve however human resources and to promote welfare to society.

To acknowledge characteristics of students from cognitive aspect point refers to theory : the growing cognitive of human taking place continuously along with one's intellectual develop up. Piaget distinguished cognitive development of human as formal operational stage is formal gentle taking place 12 years above. On this stage, one shall be able to think logically without any present of concrete objects as a learning media.

It should be noted that an assessment model also influencing to ability of thinking. According to Van den Berg (2008, p.15) that curriculum has a richly potency to develop mainly on high order think skill, therefore a teacher must plan properly and involve the students in a learning activity in order to push and develop a high order think skill available.

An assessment should be done to help student in improve their go to a high order think skill with reasonable that high order think may push students to think deeply about the lesson (Barnmett \& Francis (2012, p.209). By these two opinions can be concluded that a high order think skill test may give stimulation and lead them to have a high order think skill. Nitko \& Brookhart (2011, p.223) recognized that basic rule to assess a high order think skill is by making assignments requires uses of knowledge and skill in new situation. In order to make 
assessment on a higher order thinking there must use new materials. One of the methods is by having item sets depending on context.

A high order think skill is rather mental activities happen to someone dealing with problems or situation need to solve. Thinking activity can be classified into a lower order thinking and also higher order thinking. According to Heong, et. Al (2011) existing a high order think skill is defined as how to think widely to find new challenge. In this high order think skill perhaps demanded one find new information out or knowledge previously and manipulate information to reach out possibility responds in new situation. Woolfolk (2008), acknowledged students should have high order think skill to distinguish a fact or opinion, to identify a relevant info, to solve problem, and able to take conclusion. The process of high order think correlated with three dimensions about thought and learning. First, think order can be freed from a learning order even is mutual depended. Second, think correlated with content of material in learning may help knowing a high order think skill. Third, a high order think encountered with various thinking process applied on a complex situation and has many variables (King, et al.).

The learning tool to develop such : learning material, RPP, evaluation instrument, learning implementation, learning model of TPS, and LKS that taught in a TPS learning of social arithmetic with ability to think high order. The development of learning tool in social arithmetic should be valid, practical and effective. This professional competency certainly urged all teacher obliged to arrange a learning tool completely and systematic to run the learning be interactively, inspired initiative to create and moved to develop the learning tools.

The learning tool is a devices used in a learning process (Trianto, 2011: 201). Some learning tools used such as : RPP, syllabus, LKS, books and evaluation instrument. In order to generate a qualified tools that learning tools should be arranged properly.

\section{Coopperative Learning}

\section{LIBRARY REVIEW AND RESEARCH ROAD MAP}

Adopting cooperative learning type thing pair and share method in a story telling certainly multiply interested and wishing attend the learning usually collaborated with friends. The telling story model, then in second stage (pair) used there a paired storytelling model or pair telling.

A teaching technique of paired storytelling is noted an interactive approach between students, teacher, and material (Lie, 2004). In pair, student can share each other in dealing with problems by telling in class before friends. On stage share, student get opportunity to explore participation to other. Thin-pair share as one of types in a cooperative learning may promote opportunity to student in think, in pair or with partner, then share and to help each other, aimed at adding variety of learning model be more attractive, funny, drive activity up and promote cooperation.

In such typed learning however bear student as subject of learning. The advantages of cooperative learning type think-pair-share is to optimize students' participation. Compared to a classical method that involved one student only go-forward and share the results to all, this type think-pair-share may contribute at least eight time more to student in knowing and show their participation to others (Lie, 2004:57).

The type think-pair-share learning is one of simply cooperative learning models having procedure exposed explicitly in order to make cooperative learning of type think-pair-share be easy done. 
The cooperative learning type think-pair-share is able to help student to deal with problem for telling. In pair telling story model may reduce individual stress while telling. According to Kagan (1994) the profit of cooperative learning type think-pair share then be more enthusiastic student to take part and respond following get practiced with mate. It seemly mostly students required additional time to wait, also their responds be more quality, and (2) the teachers also possibly have more time to think while adopted think-pair-share model. They can be concentrated to hear others' opinion, to monitor students' reaction, and then ask questions in highly order. Still, Lie (2005: 46) notified that advantages with pair group, either : (1) promote participation by student in a learning process, (2) this model group is properly to a simple assignment, (3) each student has equal opportunity to implement cooperative learning more and contribute in own group, (4) interacted in group is easy to done, and (5) make group be more fast and easily.

Cooperative learning of student pair telling type can be more active to develop their ability in thinking and imagination ability. The cooperative learning TPS type is one of simple cooperative learning models allow opportunity each student to have process "think-pairshare" activity in attending. The stages in cooperative learning TPS type is known so simple but very important mainly to avoid any mistakes by team work.

The cooperative learning TPS type recommended those teacher asked the student to think one topic paired with other student and discuss it, then share to all mates. The stage cooperative learning method type think-pair-share according to Lyman (1981) are: (1) Thin. The teacher provokes students thinking with a question or prompt or observation (2) Pair. Using designated partners, nearby neighbors, or a deskmate, students pair up to talk about the answer each came up with. (3) Share. After students talk with pair for a few moments (again, usually not minutes), the teacher calls for pairs to share their thinking with the rest of the class. Kagan (1994) designated stages think-pair-share-involves a three step cooperative structure. During the first step individuals think silently about a question posed by the instructor. Individuals pair up during the second step and exchange thoughts. In the third step, the pairs share their responses with other pairs, other share, other teams, or the entire group.

\section{High Order think Skill}

The high order think skill as transformed from high order thinking skills (HOTS) is a thinking activity involved a high hierarchy cognitive level of thoughts taxonomy by Bloom.
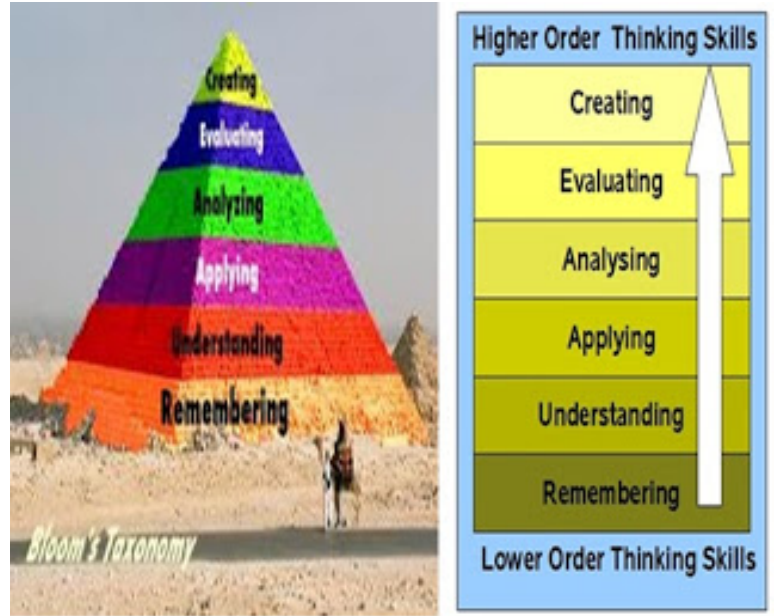

Figure 1, Structure High Order Thinking Skill 
The high order think skill is seen one of approaches for learning where the students is led to think critical, logic, reflective, meta-cognitive, and think creative. This think skill shall move up when an individual or student facing a problem that they never dealt with; that mathematics as given to all students since there equip them with logical thinking skill, to analyze, systematic, critical, and creative, and able to cooperate.

The teaching strategy properly with a good atmosphere to study may facilitate the student s' think skill and this is an essential factor to achieve this approach, supported in perseverance, personal monitor, open think, and act flexible.

In a high order think skill perhaps require logic, since then logic ability and critical think related each other. This according to statement of Krulik and Rudnick (1995: 2), that logic sense involved also basic thinking, critical thinking, and creative thinking. The last two level (critical thinking and creative thinking also notify that high order think should be improved in a social arithmetic learning.

Several main concept refers to HOTS approach in such way hold the three important thinking concept and learning, they are : thinking must be correlated with the order, they may depend each other, thinking or not thinking can study without main content, only theoretical point.

In fact life, student will study the material bases to experiences in school. In high order think covering various way of thinking, process out, and apply on combined situation and multiple variable later. The thinking order depends on correlation of real word situation with multiple variable of offer over challenge to think process out. Successful of high order think is depending on individual ability to apply, revise, and to beautify knowledge.

The teaching of think skill is based on two philosophies. First, there is a must material how to think. Secondly, to integrate the thinking activity into each learning of mathematics. So, high order think need to improve and can be part of daily learning of math. In this approach, think skill can be improved leading student become a better problem solver. Therefore, the teacher must provide question (problem) in that point allowing student explore high order think skill to respond.

In generally, the high order think skill comprising of 4 levels they are : recall thinking, basic thinking, critical thinking, and creative thinking (Krulik \& Rudnick, 1999). For a high order think skill is a cognitive ability engaged intellectual skill with capable to analyze, to combine, and evaluate all aspect of situation or problem faced any time, even still to collect, organize, remember, and to review information. Critical think involving capable to read with understand and identify material required or not. Able to take conclusion properly refers to data available and also competent to notify in-consistence and contradiction in data group as part of critical think skill.

\section{THE METHOD OF RESEARCH}

This study oriented to improvement of product which by the process should be described as accurate as possible and then evaluate them. The development process correlated with activity on each order of development. On this phase is included to testing process that applied abstract experiment.

The location of research is two units SMP Negeri - government school and one unit SMP Swasta - private in Medan. The subject of this study are those students Grade VII SMP level, still the object are material for lesson (RPP), Assessment instrument and LKS. The 
development sort to be done is 4-D model as notified by Thiagarajan, Semmel, and Semmel then modified into four steps; they are : defining, designing, development and disseminate. This study was conducted by teacher as stakeholder on Mathematics with material social arithmetic existed on SMP of Medan available universally.

In implementation, mainly to develop this mathematics learning tool need to prepare the material, syllabus, in lesson unit (SAP), assessment instrument, and formula to improve their think skill as student, mainly on aspect as arranged such as : value rate of thing in all, value per unit, and value of part, price of sale, purchasing, profit, and lost, percentage of profit or lost upon price of purchasing, gross, net, and tare, discount, deposit interest, taxes.

In detail about development the model 4D Triagrajan with phase : Define, Design, Develop and Disseminate phases. Dissemination process is the last phase. Dissemination is done to promote product to be acceptable either individual, by group, or system. Producer and distributor must be selective and to cooperate make it packed in a properly material. The dissemination can be done on other class aimed at knowing the effectiveness uses of devices in the learning process. Dissemination can be also done through transmission process to those concerned learning practices in a certain forum. The form of this dissemination is aimed at getting inputs, correction, suggestions, assessment to sound the last product improved and be ready adoptable to the user.

\section{THE RESULTS}

In dissemination phase is done at once implementation namely to analyze the impact of using think pair and share model upon high order think skill of the students. This study was done for irregular and regular semester for study year 2017/2018 on three SMP schools, two units SMP Negeri and another one unit SMP private school. Data of this study was taken original from first, second, and the third schoos.

\section{The Data Analysis of High Order Think Skill}

This first, second and third schools all are SMP in Medan, the subject to this study are students comprising of two class-room as experiment and control groups.

Following done a learning using certain material as developed then still carry out post-test this is to know the difference of result by student using a TPS model with the learning material as developed with student taught conventional. The result with post-test of the students' high order think skill can be seen on the figure below.

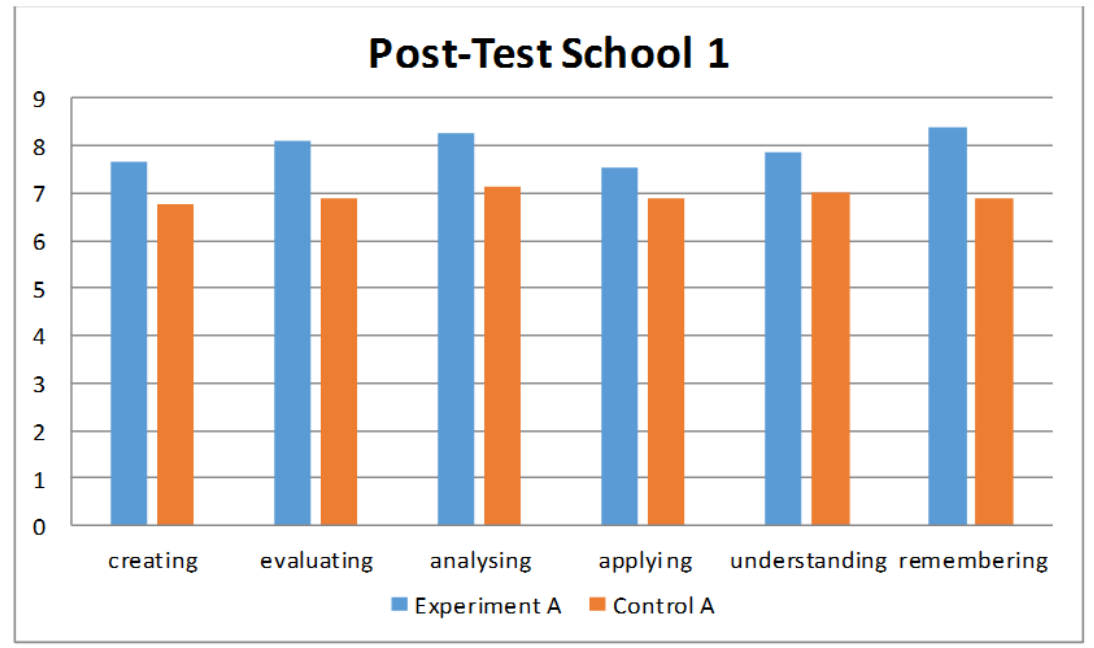

Figure 2. Post-test on high order think skill to School 1 
Figure 1 indicated that average the high order think skill of students in experiment group in all aspect of highly think aspect as measured better than control group.

The Recapitulation difference of gained value bases to rate above as seen below.

Table 1. The Difference Value Gained in Experiment Group and Control in School 1 Statistic N Gain Score on First School

\begin{tabular}{|c|c|c|c|}
\hline & Experiment 1 & Control 1 \\
\hline \multirow[t]{2}{*}{$\mathrm{N}$} & Valid & 28 & 28 \\
\hline & Missing & 0 & 0 \\
\hline \multicolumn{2}{|l|}{ Mean } & 2.01875 & 1.22857 \\
\hline \multicolumn{2}{|c|}{ Std. Error of Mean } & .122269 & .087757 \\
\hline \multicolumn{2}{|l|}{ Median } & 2.07500 & 1.25000 \\
\hline \multicolumn{2}{|l|}{ Mode } & $1.300^{\mathrm{a}}$ & 1.300 \\
\hline \multicolumn{2}{|c|}{ Std. Deviation } & .646988 & .464365 \\
\hline \multicolumn{2}{|l|}{ Variance } & .419 & .216 \\
\hline \multicolumn{2}{|l|}{ Skewness } & .006 & .423 \\
\hline \multicolumn{2}{|c|}{ Std. Error of Skewness } & .441 & .441 \\
\hline \multicolumn{2}{|l|}{ Range } & 2.700 & 1.750 \\
\hline \multicolumn{2}{|l|}{ Minimum } & .700 & .500 \\
\hline \multicolumn{2}{|l|}{ Maximum } & 3.400 & 2.250 \\
\hline \multicolumn{2}{|l|}{ Sum } & 56.525 & 34.400 \\
\hline \multirow[t]{3}{*}{ Percentiles } & 25 & 1.42500 & .92500 \\
\hline & 50 & 2.07500 & 1.25000 \\
\hline & 75 & 2.53750 & 1.47500 \\
\hline
\end{tabular}

1. Creating thinking, after data analysis obtained that Test-B-Gain Indicator Creating thinking can be taken conclusion average gain ability make creating thinking in experiment class 2.15 is higher than control class with the average gain ability of creating thinking 1.712 .

2. Evaluating thinking, then can be concluded average gain evaluating thinking to experiment group is 2.2875 is higher than average gain as control class of 1.875 .

3. Analyzing thinking, then can be concluded average gain analyzing thinking in experiment class 1.96 higher than average gain on control class of 1.12.

4. Applying thinking, than can be concluded average gain applying thinking of experiment class 1.68 higher than average gain applying thinking control class 1.26.

5. Understanding thinking, can be concluded then average gain understanding thinking in experiment class 1.72 higher than average gain on control class of 1.14 .

6. Remembering thinking, can be concluded then average gain remembering experiment class 2.2 higher than average gain on control class of 1.24 .

By the data analysis as above can be concluded that high order think skill to the first school on all aspect as measured to all aspect noted ability of think order to experiment class higher than control class. The experiment class indicated average gain score improvement is 2.018, median 2.075, mode 1.300; standard deviation 0.669; minimum score 0.700, maximum score 3.400. Whereas control group indicated average improvement gain score is 1.228; median 1.250; mode 1.300; standard deviation 0.464 ; minimum score 0.500 ; maximum score of 2.250 . 
The second schools are grade VII of government schools in Medan. Grade involved noted two class rooms such experiment class and control class. The following is presented the result of analysis high order think skill of student to School 2.

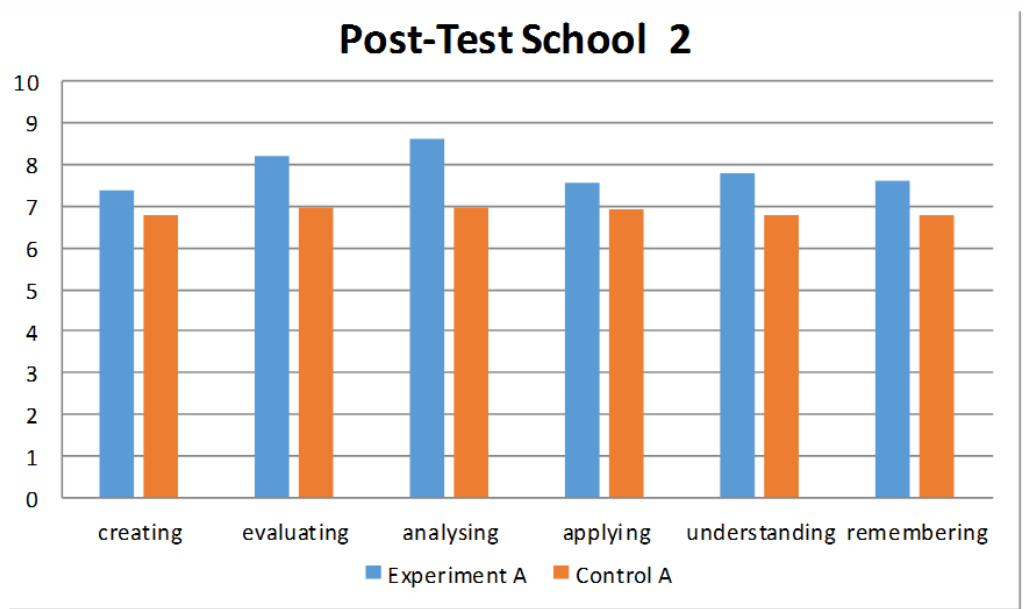

Figure 3. Result of Post-test High Order Think Skill of School 2

By the figure can be seen the high order think skill to all aspect of thinking in high for the students experiment class is better than control class. The following is presented the result of analysis data of improvement to think high of students in second school.

Total students having complete data with pre-test and post-test value 28 students. Average gain value of high order think skill on control class is 1.295 , so gain value is moderate category. Meanwhile this gain median value 1.350 , standard deviation is 0.581 , variant 0.337 . By the Table 4.2 can be seen that found rising level of $\mathrm{h}$ order think skill of students after attending TPS lesson with a lower gain risen and data spread is good.

The average gain value in experiment class 1.684, so the gain value is moderate. Still, this gain median value 1.600 , standard deviation 0.809 , variant 0.654 . By Table 4.2 can be seen that found a value in high order think skill of students after attending lesson with gain rising is moderate and data spreading is good. It is concluded that found significant different between the N-gain improvement in high order think skill on control class and experiment class. This indicated that average rising high order think skill of students on experiment class is higher than control class.

\section{The N-gain Analysis on Each Aspect Thinking High Order on Experiment Class}

Bases to the table as above seen the gain value of each indicator are as following:

1. Creating Thinking, average gain of indicator creating is 1.684 so the gain value is moderate category, still the gain median value on this group 1.600, standard deviation 0.809 , variant 0.654 .

2. Evaluating thinking, average gain of indicator evaluating thinking 1.525 so gain value is high category, still gain median value of this indicator 0.238 , standard deviation 0.509 , variant 0.234 .

3. Analyzing thinking, average gain of indicator analyzing thinking is 1.85 so gain value is high category, still gain median value of this indicator 0.000 , standard deviation 0.463 , variant 0.143 .

4. Applying thinking, average gain of indicator applying thinking 1.62 so the gain value is high category, while the gain median value on this indicator 0.9801 , standard deviation 0.678 , variant 0.143 . 
5. Understanding thinking, average gain of indicator understanding thinking is 1.542 so gain value is lower category, while gain median value of this category 0.000 , standard deviation 0.468 , variant 0.143 .

6. Remembering thinking, average gain of indicator remembering thinking is 1.875 so gain value is lower category, while gain median value of this indicator 0.546 , standard deviation 0.618 , variant 0.143 .

Referring to the above data can be noted the gain value of each indicator on the control group as following :

1. Creating thinking, average gain indicator creating thinking is 1.175 so gain value is lower category, while gain median value of this indicator 0.591 , standard deviation 0.781 , variant 0.079 .

2. Evaluating thinking, average gain indicator evaluating thinking is 1.451 so gain value is lower category, while gain median value of this indicator 0.334 , standard deviation 0.583 , variant 0.234 .

3. Analyzing thinking, average gain indicator analyzing thinking 1.122 so gain value is lower category, while gain median value of this indicator 0.462 , standard deviation 0.581 , variant 0.143 .

4. Applying thinking, average gain indicator of applying thinking is 1.36 so gain value is lower category, while gain median value of this indicator 0.508 , standard deviation 0.394 , variant 0.143 .

5. Understanding thinking, average gain indicator of applying understanding thinking is 1.056 so average gain is lower category, while gain median value of this indicator 0.353 , standard deviation 0.708 , variant 0.143 .

6. Remembering thinking, average gain indicator remembering thinking 1.325 so gain value is lower category, while gain median value of this indicator 0.507 , standard deviation 0.407 , variant 0.143 .

On the Table below can be seen the different gain on each indicator bases to the above data as following : 
Table 2 . The Difference Gain Value Experiment Class and Con Class of Second School With Statistics N Gain Score on Second School

\begin{tabular}{|c|c|c|c|}
\hline & Experiment - 2 & Control - 2 \\
\hline \multirow[t]{2}{*}{$\mathrm{N}$} & Valid & 28 & 28 \\
\hline & Missing & 0 & 0 \\
\hline \multicolumn{2}{|l|}{ Mean } & 1.68393 & 1.29464 \\
\hline \multicolumn{2}{|c|}{ Std. Error of Mean } & .152819 & .109784 \\
\hline \multicolumn{2}{|l|}{ Median } & 1.60000 & 1.35000 \\
\hline \multicolumn{2}{|l|}{ Mode } & $1.100^{\mathrm{a}}$ & 1.600 \\
\hline \multicolumn{2}{|c|}{ Std. Deviation } & .808640 & .580922 \\
\hline \multicolumn{2}{|l|}{ Variance } & .654 & .337 \\
\hline \multicolumn{2}{|l|}{ Skewness } & -.265 & -.159 \\
\hline \multicolumn{2}{|c|}{ Std. Error of Skewness } & .441 & .441 \\
\hline \multicolumn{2}{|l|}{ Range } & 2.900 & 2.400 \\
\hline \multicolumn{2}{|l|}{ Minimum } & .100 & .000 \\
\hline \multicolumn{2}{|l|}{ Maximum } & 3.000 & 2.400 \\
\hline \multicolumn{2}{|l|}{ Sum } & 47.150 & 36.250 \\
\hline \multirow[t]{3}{*}{ Percentiles } & 25 & 1.12500 & .95000 \\
\hline & 50 & 1.60000 & 1.35000 \\
\hline & 75 & 2.28750 & 1.60000 \\
\hline
\end{tabular}

The above data indicated a significant value on all indicator with $p$-value $<0.05$, so it is found difference variant score improved in high order think skill of experiment class with control class. It can be concluded that all indicator not distributed normal but homogeny, therefore to see clearly the difference on each gain is used a non-parametric statistic test namely Mann Whitney test. It can be concluded that a high order think skill of second school to all aspect as measured, ability to make model, choose strategy and apply strategy experiment class is higher than control class.

The school such one of SMP private in Medan with own accredited, taking sample in two classroom grade VII, for control class and experiment well.

After doing lesson there using a material lesson as developed thence did post-test in order to see the difference result of study those students using TPS model with the material of lesson developed with the students taught conventionally. The result of post-test of a high order think skill can be seen on Figure as below:

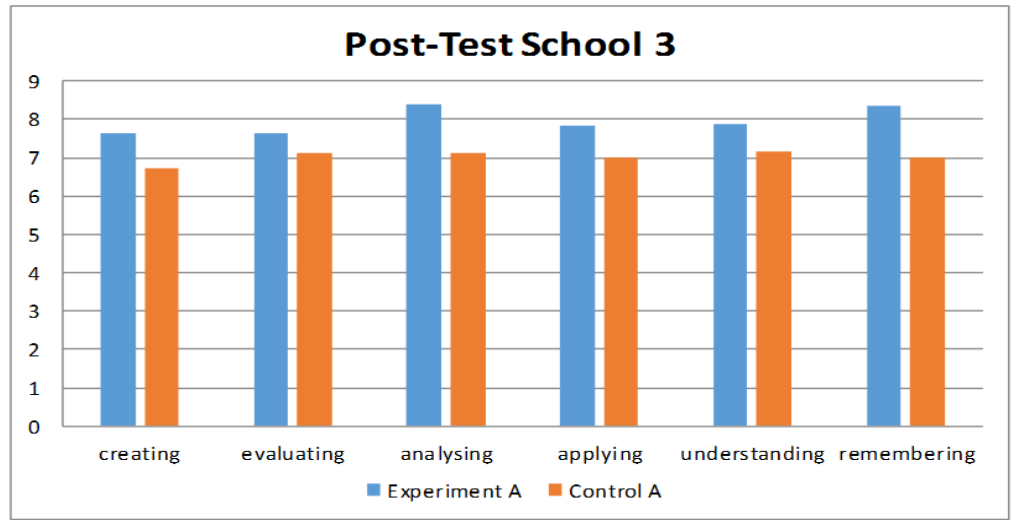

Figure 4. Diagram of Post-test on Experiment Class 
From Figure 4.3 can be seen that by six aspects of a high order think skill of students on the experiment class is noted better and on control class. This indicated average improved in high order think skill of students on experiment class is better than on control class.

\section{Analysis N-Gain on each Aspect of High Order Think Skill, by an analysis Statistics N-Gain of Control Class}

1. Creating thinking, average gain indicator creating thinking is 1.008 so the gain value is moderate category, while a gain median value of this indicator 0.363 , standard deviation 0.565 , variant 0.334 .

2. Evaluating thinking, average gain indicator evaluating thinking 1.3187 so the gain value is a moderate category, while the gain median value of this indicator 0.826 , standard deviation 0.658 , variant 0.428 .

3. Analyzing thinking, average gain indicator analyzing thinking is 0.775 so gain value is moderate category, while gain median value of this indicator 0.742 , standard deviation 0.527 , variant 0.375 .

4. Applying thinking, average gain indicator applying thinking is 1.086 so gain value is moderate category, while gain median value of this indicator 1.033, standard deviation 0.465 , variant 02134 .

5. Understanding thinking, average gain indicator of understanding thinking 1.245 so gain value is moderate category, while gain median value of this indicator 0.503 , standard deviation 0.4065 , variant 0.2104 .

6. Remembering thinking, average gain indicator of remembering thinking 0.4928 so gain value is moderate category, while gain median value of this indicator 0.393 , standard deviation 0.837 , variant 0.613 .

Bases to table as above can be noted the gain point of each indicator as followings :

1. Creating thinking, average gain indicator of creating thinking is 0.785 so gain value is lower category, while gain median value of this indicator 0.703 , standard deviation 0.605 , variant 0.434 .

2. Evaluating thinking, average gain indicator of evaluating thinking is 0.704 so gain value is lower category, while the gain median value of this indicator 0.606 , standard deviation 0.588 , variant 0.3584 .

3. Analyzing thinking, average gain indicator of analyzing thinking is 1.306 so gain value is moderate category, while gain median value of this indicator 0.625 , standard deviation 0.704 , variant 0.497 .

4. Applying thinking, average gain indicator of applying thinking 0.9032 so gain value is moderate category, while the gain median value of this indicator 0.4033 , standard deviation 0.605 , variant 0.3613 .

5. Understanding thinking, average gain indicator of understanding thinking 1.6032 so gain value is moderate category, while gain median value of this indicator 0.5032 , standard deviation 0.709 , variant 0.489 .

6. Remembering thinking, average gain indicator of remembering thinking is 2.033 so gain value is moderate category, while gain median value of this indicator 0.671 , standard deviation 0.387 , variant 0.701 .

The following table indicated the difference gain value for each indicator bases to the data as above: 
Table 3. Different Gain Value of Experiment Class and Control Class in Third School Statistics N Gain Score on Third School

\begin{tabular}{|c|c|c|c|}
\hline & & Experiment - 3 & Control - 3 \\
\hline \multirow[t]{2}{*}{$\mathrm{N}$} & Valid & 28 & 28 \\
\hline & Missing & 0 & 0 \\
\hline \multicolumn{2}{|l|}{ Mean } & 1.32321 & .9964 \\
\hline \multicolumn{2}{|c|}{ Std. Error of Mean } & .142632 & .09899 \\
\hline \multicolumn{2}{|l|}{ Median } & 1.30000 & 1.0000 \\
\hline \multicolumn{2}{|l|}{ Mode } & 1.300 & 1.38 \\
\hline \multicolumn{2}{|c|}{ Std. Deviation } & .754736 & .52382 \\
\hline \multicolumn{2}{|l|}{ Variance } & .570 & .274 \\
\hline \multicolumn{2}{|l|}{ Skewness } & .474 & -.340 \\
\hline \multicolumn{2}{|c|}{ Std. Error of Skewness } & .441 & .441 \\
\hline \multicolumn{2}{|l|}{ Range } & 3.550 & 1.95 \\
\hline \multicolumn{2}{|l|}{ Minimum } & -.100 & -.05 \\
\hline \multicolumn{2}{|l|}{ Maximum } & 3.450 & 1.90 \\
\hline \multicolumn{2}{|l|}{ Sum } & 37.050 & 27.90 \\
\hline \multirow[t]{3}{*}{ Percentiles } & 25 & .85000 & .4875 \\
\hline & 50 & 1.30000 & 1.0000 \\
\hline & 75 & 1.88125 & 1.3750 \\
\hline
\end{tabular}

So it can be concluded average gain of high order think skill of experiment class is not higher than control class. So, it can noted that a high order think skill on the third school on all aspect as measured, it is high order think skill of experiment class is higher than on control class.

\section{DISCUSSION}

This study was done upon a high order think skill and its lesson using own material of social arithmetic according to National curriculum. The results indicated that improved high order think skill of students studying using improved social arithmetic material refers to curriculum 2013 is higher than an improvement of ability by students studying with think pair and share using a conventional lesson model and it is included into moderate category. This is influenced in several factors such as the learning model used, students ability and teacher ability in managing the lesson. So, the result obtained also influenced by several factors, such as students ability, teacher and sheet assignment of students.

Bases to the result process of finishing LKS sheet can be concluded that students have skill to follow the steps to complete the problem as given, so they able to answer them properly and refers to the problem faced to. The students are joyfully this lesson due to they all can adopt various strategic to solve the problem they facing to. The solution as given with the point leading the students more understand the question and used to thinking of early steps should be done by students before having the outcome, as hoped they should finish LKS sheet assignment on the following attend.

The activity on mathematics lesson with TPS learning is noted an interactive activity between the students-teacher, students-students, and teacher-students, it means the learning taking place should be not one-way direction, the information should be not only from teacher to students as practiced so long. For those students are given opportunity to find deeper with mate in group. 
As long as the learning taking place, the lesson mathematics by this TPS learning should attract to the students that able to motivate them to hand in hand, to respect each other, share each other in group. The teacher shall act as facilitator in a learning there should be seen interaction between teacher to students, students with students and create atmosphere to develop thinking more critical and sharply in solving the problems.

By the result of study indicated that in whole the TPS point learning present and push the students to study more and the last they will improve selves in high order think skill.

\section{Conclusion}

\section{CONCLUSION AND SUGGESTIONS}

Bases to the result of analysis in data process it can be concluded as the followings:

1. By all school as the sample of school as disseminated in this study obtained that a high order think skill with TPS model learning is higher than a conventional learning.

2. The improvement in high order think skill on the third school is included into a moderate category. The gain points of the third school are as followings :

a. On the first school, improvement in high order think skill of students on each indicator are : on the experiment class all indicators such as creating, evaluating, analyzing, applying, understanding and remembering thinking is included a moderate category. For control class the indicator create a model and apply the strategy is included into a high category.

b. On the second school, improvement to high order think skill of students on each indicator of creating, evaluating, analyzing, applying, understanding, and remembering thinking on the experiment class is a high category. On a control class all indicators included into moderate category.

c. On the third school, improvement to high order think skill of creating, evaluating, analyzing, applying, understanding, and remembering thinking is high category. On the control class the indicator to make model is moderate category.

\section{Suggestions}

Bases to conclusion as above, the research present several important points, so the researcher give suggestions as following :

1. To the teacher of mathematics on school, required all TPS learning model should be according to National curriculum, since it is alternative to apply in order to improve their result of study specifically to high order think skill as students.

2. To the teacher expecting to apply them on social arithmetic may design/ create self own a learning tool as required, considering there available a learning approach components and with characteristics in material of social arithmetic as developed.

\section{References}

Akker, J. van den. 1999. Principles and Methods of Development Research. Dalam Plomp, T; Nieveen, N; Gustafson, K; Branch, R.M; dan van den Akker, J (eds). Design Approaches and Tools in Education and Training. London: Kluwer Academic Publisher.

Amir, M.T. 2009. Inovasi Pembelajaran Pendidikan Melalui Problem Based Learning: Bagaimana Pendidik MemberdayakanPemelajar di Era Pengetahuan. Jakarta: Kencana

Brookhart, S. M. (2010). How to assess higherorder thinking skills in your classroom. Alexandria: ASCD. Depdiknas. 2008. Panduan Pengembangan Bahan Ajar. Jakarta: Depdiknas.

ECD. (2013). PISA 2012 assessment and analytical framework: mathematics, reading, science, problem solving and financial literacy. German: OECD Publishing. 
OECD. (2014). PISA 2012 results in focus: What 15 year olds know and what they can do with what they know. German: OECD Publishing.

Fachrurazi. 2011. Penerapan Pembelajaran Berbasis Masalah untuk Meningkatkan Kemampuan Berpikir Kritis dan Komunikasi Matematis Siswa Sekolah Dasar. Jurnal: tidak diterbitkan.

Hillman, W. 2003. Learning How to Learn: Problem Based Learning. Australian Journal of Teacher Education, 28 (2): $1-10$.

Istiyono, E., Mardapi, D., \& Suparno. (2014). Pengembangan tes kemampuan berpikir tingkat tinggi fisika (PysTHOTS) peserta didik sma

Kemampuan Berpikir Tingkat Tinggi Siswa SMP Dian Kurniati, Romi Harimukti, Nur AsiyahJamil155http://ejournal.unsri.ac.id/index.php/jpm/article/view/326/89. OECD. (2013).

Lewy, Zulkardi, \& Aisyah, N. (2009). Pengembangan soal untuk mengukur kemampuan berpikir tingkat tinggi pokok bahasan barisan dan deret bilangan di kelas IX akselerasi SMP Xaverius Maria Palembang.

Padmavathy \& Mareesh. 2013. Effectiveness of Problem Based Learning in Mathematics. International Multidisciplinary e-Journal, 2 (1): 45 - 51.

Pargaulan Siagian, Erlinawaty Simanjuntak, and Katrina Samosir. Prototype Teaching Mathematics in Improving Critical Thinking Ability of Senior High School Students. International Journal of Innovation in Science and Mathematics. Vol. 5, Issue 2 ISSN (online). 2347 -9051.

PISA 2012 assessment and analytical framework: mathematics, reading, science, problem solving and financial literacy.

Rochmad. 2012. Desain Model Pengembangan Perangkat Pembelajaran. Jurnal Kreano, 3 (1): 59 - 72

Rohman \& Amri. 2013. Strategi dan Desain Pengembangan Sistem Pembelajaran. Jakarta: Prestasi Pustaka

Rusman. 2011. Model-Model Pembelajaran: Mengembangkan Peofesionalisme Guru. Jakarta: PT Raja Grafindo Persada

Siagian Pargaulan, Simanjuntak Erlinawaty, and Samosir Katrina. Prototype Teaching Mathematics in Improving Critical Thinking Ability of Senior High School Students. International Journal of Innovation in Science and Mathematics. Vol. 5, Issue 2 ISSN (online). 2347 -9051

Setiawan, H. (2014). Soal matematika dalam PISA kaitannya dengan literasi matematika dan keterampilan berpikir tingkat tinggi. In Prosiding Seminar Nasional Matematika, Universitas Jember.

Sudrajat, A. (2011). Kemampuan menganalisis dalam pembelajaran. Retrieved October 27, 2015, from https://akhmadsudrajat.wordpress.com/2011/05/08/kemampuan menganalisis-dalam-pembelajaran/Sugiyono. (2010). Memahami penelitian kualitatif. Bandung: CV. Alfabeta.

Thiagarajan, S. dkk. 1974. Instructional development for Training Teachers of Exceptional Children A Sourcebook. Minnesota: National Center For Improvement of Educational System.

Trianto. 2011. Mendesain Model Pembelajaran Inovatif Progresif. Jakarta: Kencana Prenada Media Group.

Wardhani, S. (2015). Pembelajaran dan penilaian aspek pemahaman konsep, penalaran dan komunikasi, pemecahan masalah. Retrieved April 23, 2015, from http://p4tkmatematika.org/file/PRO DUK/PAKET FASILITASI/SMP/Standar Penilaian Pendidikan.pdf

Wiyana, dkk. 2013. Pengaruh Pengetahuan KTSP dan Pendidikan Terhadap Kemampuan Menyusun RPP Guru SDN Jatiyoso Tahun 2011/2012. Jurnal Teknologi Pendidikan, 1 (2): 239-248 (http://jurnal.pasca.uns.ac.id)

Yudhanegara, M. R. (2012). Taksonomi bloom. etrieved October 27, 2015, from http://mridwanyudhanegara.blogspot. co.id/2012/03/taksonomi-bloom.html 